\title{
Erratum to: Decreasing Recurrence Rates for Ductal Carcinoma In Situ: Analysis of 2996 Women Treated with Breast-Conserving Surgery Over 30 Years
}

Preeti Subhedar, MD ${ }^{1}$, Cristina Olcese, BS $^{1}$, Sujata Patil, PhD $^{2}$, Monica Morrow, MD, FACS ${ }^{1}$, and Kimberly J. Van Zee, MS, MD, FACS ${ }^{1}$

${ }^{1}$ Breast Service, Department of Surgery, Memorial Sloan Kettering Cancer Center, New York, NY

${ }^{2}$ Department of Epidemiology and Biostatistics, Memorial Sloan Kettering Cancer Center, New York, NY

ERRATUM TO: ANN SURG ONCOL (2015) 22:3273-3281

DOI 10.1245/S10434-015-4740-8

In the XML of the original article, Kimberly J. Van Zee's given name was tagged incorrectly. This erratum corrects the error.

The online version of the original article can be found under doi:10.1245/s10434-015-4740-8.

(C) Society of Surgical Oncology 2015

Published Online: 29 Sep 2015

K. J. Van Zee, MS, MD, FACS

e-mail: vanzeek@mskcc.org 